\title{
AN APPROACH FOR COLLECTION OF NEARFIELD GROUNDWATER SAMPLES IN SUBMERGED LIMESTONE CAVERNS
}

\section{PRISTOP ZA ZBIRANJE VZORCEV PODZEMNE VODE V POTOPLJENIH APNENČASTIH JAMAH}

\author{
Aaron L. MILLS ${ }^{*}$, Terrence N TYSALL ${ }^{2} \&$ Janet S. HERMAN ${ }^{1}$
}

\begin{abstract}
UDC 551.444:543.3

Aaron L. Mills, Terrence N Tysall \& Janet S. Herman: An approach for collection of nearfield groundwater samples in submerged limestone caverns

Walls of submerged caves feeding Florida springs are often lined with a heavy mat of filamentous bacteria, many of which are able to oxidize reduced sulfur in groundwater migrating from the porous bedrock into the cave conduit. To determine changes in water chemistry as water passes through the microbial mat, a simple device made from standard well screen and sealed with a rubber stopper and controllable vents was installed in a hole drilled in the wall of the cave passage. The sampler was sealed in place with marine epoxy. We measured anions in water from the sampler and from the water-filled conduit taken just outside the sampler. Most anions measured viz., $\mathrm{Cl}^{-}, \mathrm{NO}_{3}^{-}$, and $\mathrm{PO}_{4}^{3-}$, increased slightly between the matrix and conduit waters. However, traces of sulfide were measured in the water from the rock matrix, but not in the conduit. $\mathrm{SO}_{4}^{2-}$ concentrations in the conduit were about twice that measured in the water from the sampler, about 22 and $11 \mathrm{mg} \mathrm{SO}_{4}^{2-} \mathrm{L}^{-1}$, respectively, providing further evidence that sulfur oxidation is an important process in the bacterial mats attached to the limestone surfaces in these caves. An additional use of the sampling device is to measure discharge from the local bedrock into the cave conduit.
\end{abstract}

Izvleček

UDK 551.444:543.3

Keywords: sulfur oxidation, bacteria, acid dissolution, groundwater chemistry.

Aaron L. Mills, Terrence N Tysall \& Janet S. Herman: Pristop za zbiranje vzorcev podzemne vode $v$ potopljenih apnenčastih jamah

Stene potopljenih jam, ki napajajo floridske izvire, so velikokrat pokrite $\mathrm{z}$ debelimi oblogami vlaknastih bakterij. Te lahko oksidirajo reducirano žveplo v podtalnici, ki pronica iz porozne matrice $\mathrm{v}$ jamski kanal. Da bi določili spreminjanje kemijske sestave vode, ko ta prehaja skozi mikrobsko oblogo, smo v vrtino, izvrtano $\mathrm{v}$ jamsko steno, namestili enostavno napravo, narejeno iz perforirane cevi za zaščito vrtin ter gumijastega zapirača s prilagodljivimi odprtinami za vzorčenje. Vzorčevalnik smo pritrdili z epoksi lepilom. Primerjali smo koncentracije smo anionov v vodi vzorčeni $\mathrm{z}$ vzorčevalnikom in vodi iz jamskega kanala. Koncentracija večine anionov, npr. $\mathrm{Cl}^{-}, \mathrm{NO}_{3}^{-}$, and $\mathrm{PO}_{4}^{3-}$, je v kanalu nekoliko večja, kot v porozni matrici. Sulfide smo merili le v vodi porozne matrice. Koncentracija $\mathrm{SO}_{4}^{2-}$ je v prevodniku je bila $22 \mathrm{~g} / \mathrm{L}$, v vzorčevalniku pa $11 \mathrm{~g} / \mathrm{L}$, kar kaže na to, da je oksidacija žvepla pomemben proces $\mathrm{v}$ bakterijskih oblogah, ki prekrivajo apnenčaste stene $\mathrm{v}$ jamah. Vzorčevalnik je uporaben tudi za merjenje pretoka iz lokalne matične kamnine v prevodnik.

Ključne besede: oksidacija žvepla, bakterije, raztapljanje s kislino, podzemna voda, kemija.

\footnotetext{
${ }^{1}$ Laboratories of Microbial Ecology and Aqueous Geochemistry, Department of Environmental Sciences, University of Virginia, P.O. Box 400123, Charlottesville, VA 22904-4123

2 The Cambrian Foundation, 1572 Lawndale Circle, Ste. A, Winter Park, FL 32792

${ }^{\star}$ Corresponding Author, e-mail: amills@virginia.edu

Received/Prejeto: 1.2.2013
} 


\section{INTRODUCTION}

Water enriched in reduced sulfur is common in many karst terranes, and communities of microorganisms found in the aphotic portion of subaerial and submerged caves in such locations are often rich in sulfur-oxidizing, autotrophic bacteria (Brigmon et al. 1994; Chen et al. 2009; Engel et al. 2003; Franklin et al. 2005b; Sarbu et al. 1996; Vlasceanu et al. 2000). Such microbes gain energy from the oxidation of reduced sulfur to intermediate or fully oxidized species. The reactions are well defined (Erlich 1996; Stumm \& Morgan 1996), and the products are commonly found in cave waters fed by sulfur-containing groundwater.

Reduced sulfur $\left(\mathrm{H}_{2} \mathrm{~S}, \mathrm{HS}^{-}\right)$is common in groundwater in central Florida (Sacks 1996). In many submerged caves, including the two that are examined in the present report, the conduits are covered with a mat of filamentous microorganisms, and the mats usually contain a large proportion of cells easily identifiable as sulfur oxidizers by the presence of visible grains of sulfur within the filaments (Franklin et al. 2005b). The most likely scenario to remove sulfide from the groundwater involves the oxidation of sulfide to $\mathrm{S}^{0}$ and then to $\mathrm{SO}_{4}^{2-}$ as the water passes through the mat. Protons resulting from the oxidation reaction culminating in $\mathrm{SO}_{4}^{2-}$ might accel- erate the dissolution of the host limestone, such that speleogenesis occurs faster where there is prolific growth of sulfur-oxidizing microbes (Engel \& Randall, 2011; Engel et al. 2004; Franklin et al. 2005b; Vlasceanu et al. 2000). The microbiological acceleration of conduit enlargement is termed biospeleogenesis (Barton \& Luiszer, 2005). To help define that mechanism, we developed an approach that allows comparison of water from within the conduit to that within the bedrock immediately proximal to the sampling site.

To determine the extent of chemical change in the water as it discharges from the limestone formation proximal to the cave conduit as a means to inform geochemical modeling of sulfuric acidogenesis and carbonate dissolution, we describe a simple approach for collecting samples of water from within the formation "behind" the bacterial mat. We also describe a means of using the installed sampler to estimate discharge of water across the face of the wall, useful in quantifying the extent of geochemical processes constituting biospeleogenesis. We report the results of analysis of samples collected with the device(s) to show the kinds of information that can be gained from these samplers.

\section{METHODS}

SAMPLER DESIGN AND CONSTRUCTION. The sampling device is simply a cased well with appropriate sampling ports that is installed in the wall of the submerged cave. The sampler itself was constructed from a length of 1-inch diameter $(3.3 \mathrm{~cm} \mathrm{OD} \times 2.4 \mathrm{~cm} \mathrm{ID)} \mathrm{PVC}$ well screen with slots $(0.01$ inches $[0.254 \mathrm{~mm}]$ wide). This screen is standard for monitoring wells, and it can be purchased at any driller supply outlet. For our applica- tion, sections of screen were cut about $14 \mathrm{~cm}$ in length (See Fig. 1.). One end of the screen section was closed with a rubber stopper that had two 6-inch-long, 14-gauge syringe needles inserted nearly to the hub. One of the needles was cut off so that it opened at the inner face of the stopper within the chamber. Because the samplers were to be installed into the face of a rock wall and sealed, one of the needle hubs was bent slightly to allow access of the

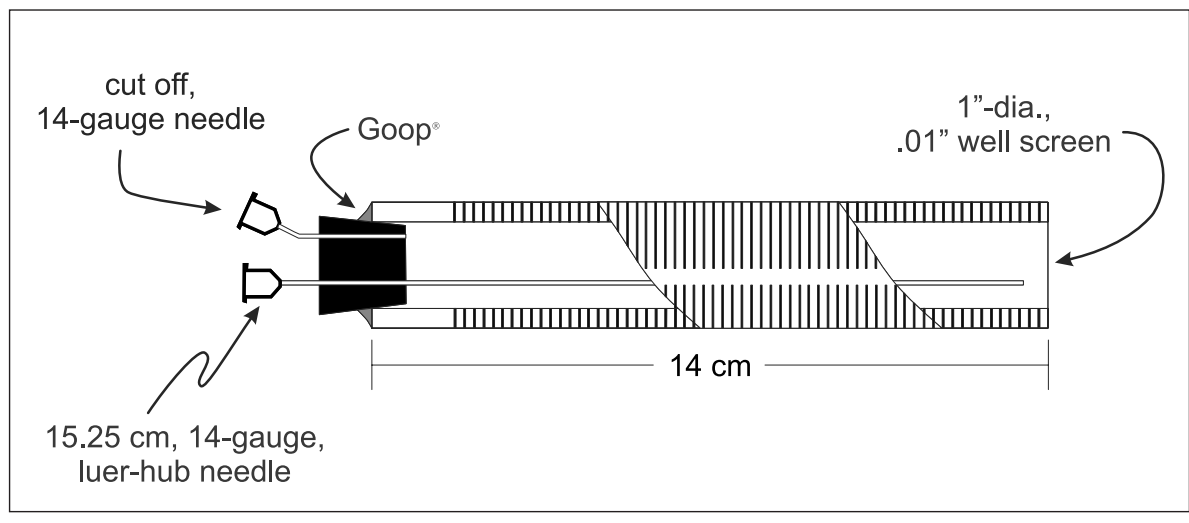

Fig. 1: Design of the formationwater sampler. 
hubs by multiple syringes. Additionally, the shorter hub was marked with a cable tie so that divers could tell the short and long needles apart. The stopper was sealed into the well screen with Plumbing Goop ${ }^{\circledR}$ (Eclectic Products, Inc., Eugene, OR, available at most hardware and home improvement stores). Other sealants would likely also be satisfactory, but we have found Goop ${ }^{\circledR}$ to be a good adhesive and excellent sealant for underwater applications.

\section{SAMPLER INSTALLATION}

Samples of conduit water and water from within the cave walls were taken at two freshwater springs in central Florida, Wekiwa Spring $\left(28.711910^{\circ} \mathrm{N}, 81.460214^{\circ} \mathrm{W}\right)$ and DeLeon Spring $\left(29.134246^{\circ} \mathrm{N},-81.362766^{\circ} \mathrm{W}\right)$ by a dive team from The Cambrian Foundation. The springs are unconnected, but both discharge to the St. Johns River. At Wekiwa Spring, three samplers were installed in No-Mount Cave at increasing depth in the cave conduit: $3.7 \mathrm{~m}, 6.1 \mathrm{~m}$, and $10.1 \mathrm{~m}$ below the surface of the water in the spring pool. At DeLeon Spring, a single sampler was deployed about $20 \mathrm{~m}$ below the free water surface in the spring pool. The particular points at which the samplers were placed had visible bacterial mat present, a small area of which was scraped away to make space for the sampler chamber to be installed.

Placement of samplers into the wall of each submerged cave was done by experienced cave divers. A pneumatic drill was attached to a scuba tank, and the drill was fitted with a 1-inch masonry bit of sufficient length to bore a hole about $15 \mathrm{~cm}$ into the rock. The divers carried the drill and tank to the proper location, bored a hole in the wall, and fitted the sampler snugly into the opening until the top of the well-screen section was about flush with the rock-wall surface. The sampler was then sealed in place with a marine epoxy suitable for underwater work. This installation left the two needle hubs protruding from the wall. Between samplings, groundwater discharging from the wall passes freely through the sampler chamber, through the needles and into the cave conduit.

\section{WATER SAMPLING}

The chamber created by drilling the hole and inserting the sampler has a void volume of about $125 \mathrm{~mL}$. Removal of water from the interior of the embedded samplers was done by displacement of the water with sterile distilled water (SDW). A 60-mL syringe filled with SDW and closed with a stopcock was carried by the divers who collected samples. The syringe was connected to the longer of the two needles inserted into the sampler through the rubber stopper (Fig. 2). An empty 10-mL syringe with a closed stopcock was then attached to the short needle.

The stopcocks were opened and SDW from the larger syringe was slowly expressed into the back of the sampler forcing the water that the sampler had contained into the smaller syringe. It is often necessary for a second diver to withdraw the plunger of the smaller syringe slowly to facilitate entry of the water into the syringe. When the smaller syringe was filled, the stopcock was closed and the syringe was placed into a bag for return to the surface. Then a second $10-\mathrm{mL}$ syringe was attached to the needle hub. This syringe contained $5.0 \mathrm{~mL}$ of $10 \mathrm{mM}$ $\mathrm{Zn}$ acetate to act as a fixative to preserve dissolved sulfide for later analysis (Cline 1969). When the syringe was full to the 10 -mL mark, the stopcock was closed and the assembly was detached from the sampler and placed in the bag for return to the surface. The $60-\mathrm{mL}$ syringe was then closed, and it was also placed in the bag with the others. Additional water samples from the cave conduit immediately adjacent to the sampler were collected in sterile, plastic $50-\mathrm{mL}$ screw-cap centrifuge tubes that were then sealed and placed in the bag with the other samples for return to the surface. On the surface, the samples were placed in coolers with ice or synthetic cold packs and returned to the laboratory for analysis.

\section{LABORATORY ANALYSES}

Water from the cave conduit and from within the porous limestone was returned to the laboratory in Virginia for analysis. Shipments were sent by overnight courier and were kept cold with frozen, synthetic cold packs. For this study, samples were analyzed for anion concentration. The anions $\mathrm{Cl}^{-}, \mathrm{SO}_{4}^{2-}, \mathrm{NO}_{3}^{-}$, and $\mathrm{PO}_{4}^{3-}$, were analyzed by ion chromatography (Dionex ICS2100 equipped with an AS4 anion column). Total dissolved sulfide (i.e., sum of $\mathrm{H}_{2} \mathrm{~S}, \mathrm{HS}^{-}$, and $\mathrm{S}^{2-}$ ) concentration was determined by colorimetry using Cline's reagent (Cline, 1969) as described by Otte and Morris (1994).

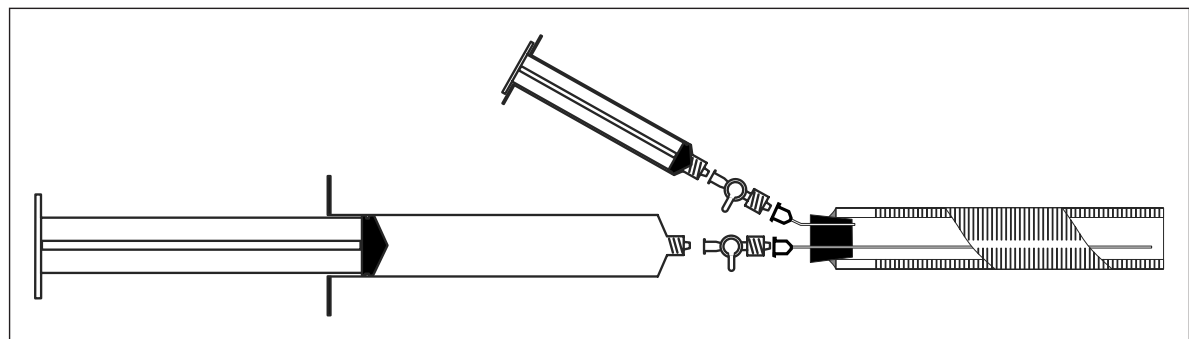

Fig. 2: Sampler as configured for sample withdrawal. Sterile distilled water is expressed from the larger syringe into the chamber, displacing water collected in that chamber into the smaller syringe. The diagram is "exploded" to show the various parts used in effecting the sample transfer. 


\section{DETERMINATION OF SPECIFIC DISCHARGE (SEEPAGE)}

Given that the samplers do not impede flow of water from the wall of the cave into the cave opening, rather they merely channel the flow through the needle hubs, the samplers can be used to determine specific discharge from the walls into the cave (i.e., seepage). The general approach employed here was developed in the late 1970s (Lee 1977; Lock \& John, 1978) and has been used in lakes, sandy-bottomed streams, and estuarine and coastal locations to measure inseepage (Flewelling et al. 2012; Holly et al. 2003). To collect the water passing through the needle hubs, a $60-\mathrm{mL}$ syringe was cut to obtain a section of the syringe barrel about $3.5 \mathrm{~cm}$ long, including the male Luer-lock tip. A latex condom was then placed over the larger end of the syringe tip and secured in place with two short nylon cable ties placed around the unit such that the clasps were on opposite sides of the barrel of the syringe tip (Fig. 3). The use of two cable ties is essential to obtain a good seal of the condom to the syringe barrel. Use of several different chemical sealants

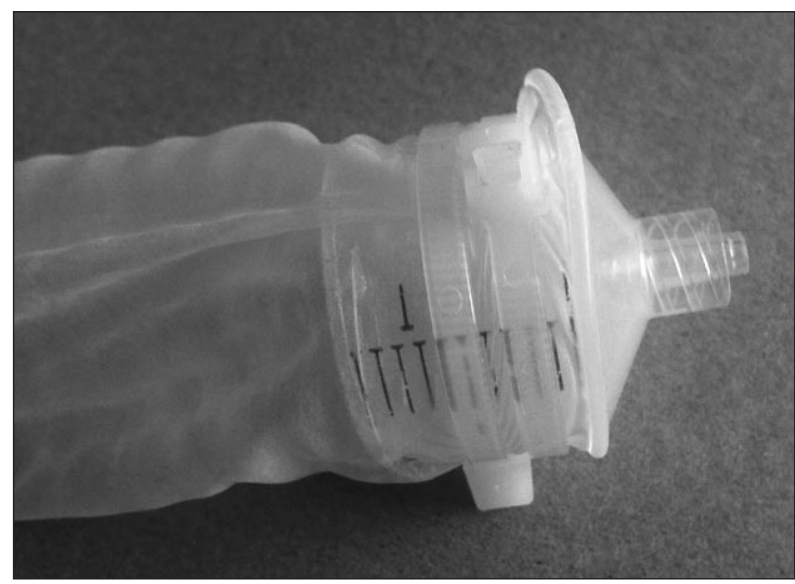

Fig. 3: Condom attached to a 60-mL syringe tip as used to collect seepage passing through the sampler. always resulted in disintegration of the condom where it contacted the sealant material. A stopcock (Cole Parmer, YO-30600-25) was attached to the syringe tip, the air expelled from the condom and the stopcock closed, and the apparatus taken to the sampler location by a diver. The unit was attached to the short-needle hub in the sampler. A stopcock was also placed on the long-needle hub and closed to prevent water from passing through that opening (Fig. 4).

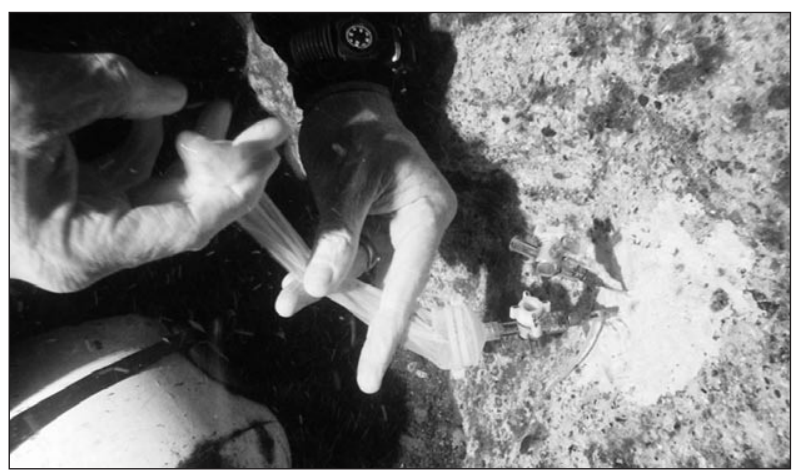

Fig. 4: Deployed sampler fitted with condom attachment for measurement of discharge of groundwater across the face of the cave wall.

The stopcock on the discharge-collecting-condom device was then opened and the time recorded. After a period of time (variable, up to about 2 hours for this study), the stopcock was closed, the time was recorded, the device was detached and brought to the surface, and the water was expelled into a small graduated cylinder to measure its volume.

Specific discharge (q) was determined as the total discharge $(\mathrm{Q}, \mathrm{mL}$ of water collected / total collection time, divided by the cross sectional area of the sampler calculated based on the inner diameter of the well screen being $2.4 \mathrm{~cm}$ ).

\section{RESULTS}

\section{ANIONS}

Most of the anions measured by ion chromatography were slightly higher in the water collected from the cave conduit as compared to the water collected from within the cave wall (Tab. 1). At both Wekiwa and DeLeon Springs, $\mathrm{Cl}^{-}$concentrations in the cave conduit were higher than those in water from within the wall, and $\mathrm{Cl}^{-}$concentrations in all samples from DeLeon Springs were higher than all samples from Wekiwa Springs. Nitrate was also higher in the cave than in the wall, with differences on the order of 1-3 $\mathrm{mg} \mathrm{L}^{-1}$. Phosphate was often not seen in one or both samples, but the chromatographic system used for the analysis was not optimized for $\mathrm{PO}_{4}^{3-}$, such that low concentrations $\left(<1 \mathrm{mg} \mathrm{PO}_{4}^{3-} \mathrm{L}^{-1}\right)$ were often not detected (even in standards). Sulfate was also higher in the cave conduit than in the cave wall, but the absolute differences seen were substantially larger than any of the other anions. For all of the sample pairs, the water gained 
Tab. 1: Concentration of selected ions in water from Wekiwa Springs and DeLeon Springs caves (July 2012). Values in parentheses indicate the depth of the sampler below the water surface. bdl=below detection limit. Detection limits were: $\mathrm{Cl}^{-}, 0.1 \mathrm{mg} \mathrm{L}^{-} ; \mathrm{sulfide,} 0.05 \mathrm{mg}$ $\mathrm{L}^{-1}$; $\mathrm{SO}_{4}^{2-}, 0.1 \mathrm{mg} \mathrm{L}^{-} ; \mathrm{NO}_{3}^{-}, 0.1 \mathrm{mg} \mathrm{L}^{-} ; \mathrm{PO}_{4}^{3-}, 0.1 \mathrm{mg} \mathrm{L}^{-1}$; dissolved $\mathrm{O}_{2}, 0.1 \mathrm{mg} \mathrm{L}^{-}$.

\begin{tabular}{|c|c|c|c|}
\hline Location & Analyte & Wall $\left(\mathrm{mg} \mathrm{L}^{-1}\right)$ & Conduit $\left(\mathrm{mg} \mathrm{L}^{-1}\right)$ \\
\hline \multirow{7}{*}{ Deleon Spring (20 m) } & $\mathrm{Cl}^{-}$ & 97.5 & 108.1 \\
\hline & Sulfide-S & 0.09 & bdl \\
\hline & $\mathrm{SO}_{4}^{2-}$ & 11.0 & 23.0 \\
\hline & $\mathrm{NO}_{3}^{-}$ & 0.8 & 3.5 \\
\hline & $\mathrm{PO}_{4}^{3-}$ & bdl & bdl \\
\hline & Dissolved $\mathrm{O}_{2}$ & Not measured & 0.41 \\
\hline & $\mathrm{pH}$ & 8.0 & 7.4 \\
\hline \multirow{7}{*}{ Wekiwa Deep (10.1 m) } & $\mathrm{Cl}^{-}$ & 15.8 & 17.8 \\
\hline & Sulfide-S & 0.08 & bdl \\
\hline & $\mathrm{SO}_{4}^{2-}$ & 11.5 & 21.4 \\
\hline & $\mathrm{NO}_{3}^{-}$ & 2.3 & 3.6 \\
\hline & $\mathrm{PO}_{4}^{3-}$ & bdl & 0.4 \\
\hline & Dissolved $\mathrm{O}_{2}$ & 0.12 & 0.63 \\
\hline & $\mathrm{pH}$ & 8.2 & 7.4 \\
\hline \multirow{7}{*}{ Wekiwa Mid (6.1 m) } & $\mathrm{Cl}^{-}$ & 16.5 & 17.9 \\
\hline & Sulfide-S & bdl & bdl \\
\hline & $\mathrm{SO}_{4}^{2-}$ & 14.2 & 22.6 \\
\hline & $\mathrm{NO}_{3}^{-}$ & 1.5 & 3.5 \\
\hline & $\mathrm{PO}_{4}^{3-}$ & bdl & bdl \\
\hline & Dissolved $\mathrm{O}_{2}$ & 0.43 & 0.30 \\
\hline & $\mathrm{pH}$ & 8.1 & 7.4 \\
\hline \multirow{7}{*}{ Wekiwa Shallow (3.7 m) } & $\mathrm{Cl}^{-}$ & 16.6 & 17.9 \\
\hline & Sulfide-S & 0.09 & bdl \\
\hline & $\mathrm{SO}_{4}^{2-}$ & 14.1 & 22.4 \\
\hline & $\mathrm{NO}_{3}^{-}$ & 2.0 & 3.5 \\
\hline & $\mathrm{PO}_{4}^{3-}$ & bdl & bdl \\
\hline & Dissolved $\mathrm{O}_{2}$ & 3.6 & 0.33 \\
\hline & $\mathrm{pH}$ & 8.2 & 7.4 \\
\hline
\end{tabular}

8-12 $\mathrm{mg} \mathrm{SO}_{4}^{2-} \mathrm{L}^{-1}\left(2.7-4 \mathrm{mg} \mathrm{S} \mathrm{L}^{-1}\right)$ between the cave wall and the conduit. Sulfide concentrations were very low in all samples. Formation water typically contained 0.08 $0.09 \mathrm{mg}$ sulfide- $\mathrm{S} \mathrm{L}^{-1}$, although at the mid-depth station in Wekiwa Spring, sulfide was below detection. In neither Wekiwa Spring nor DeLeon Spring was sulfide detected in water from the cave conduit. Previous sampling of the conduit water feeding both springs has never shown sulfide (R. B. Franklin, unpublished data and (Franklin et al. 2005a; 2005b)). Presumably, the sulfide was oxidized by the sulfur-oxidizing bacteria that dominate the microbial mats found lining the walls within the caves that feed both these springs. Identification of the organisms provided by Franklin et al. (2005a; 2005b) confirmed that the organisms were, indeed, sulfur oxidizers.

Tab. 2: Groundwater discharge into Wekiwa and Deleon Springs. July 2012. Reported values represent discharge across the cross sectional area of the sampler, viz., $4.52 \mathrm{~cm}^{2}$.

\begin{tabular}{lccccc}
\hline Spring & Sampling Depth & $\begin{array}{c}\text { Sampling } \\
\text { duration }(\mathrm{min})\end{array}$ & $\begin{array}{c}\text { Water Volume } \\
\text { recovered }(\mathrm{mL})\end{array}$ & $\begin{array}{c}\mathrm{Q} \\
\left(\mathrm{m}^{3} \mathrm{~min}^{-1}\right)\end{array}$ & $\begin{array}{c}\mathrm{q}(\mathrm{Q} / \mathrm{A}) \\
(\mathrm{m} \mathrm{min})\end{array}$ \\
\hline \multirow{3}{*}{ Wekiwa } & $3.7 \mathrm{~m}$ & 83 & 1.8 & $2.2 \times 10^{-8}$ & $4.8 \times 10^{-9}$ \\
& $6.1 \mathrm{~m}$ & 25 & 5.9 & $6.9 \times 10^{-8}$ & $1.5 \times 10^{-8}$ \\
DeLeon & $10.1 \mathrm{~m}$ & 60 & 21.0 & $3.5 \times 10^{-7}$ & $7.7 \times 10^{-8}$ \\
& & & & & $1.6 \times 10^{-7}$ \\
\end{tabular}




\section{SPECIFIC DISCHARGE}

Discharge from the limestone bedrock through the cave walls to the cave conduit was measureable in relatively short time periods ( $<1$ to ca. $2.5 \mathrm{hr}$.) at every sampling location (Tab. 2). In Wekiwa Spring, where sampling was done at different depths, discharge increased with depth. Specific discharge at the $10.1-\mathrm{m}$ sampling point was over an order of magnitude greater than that at $3.7 \mathrm{~m}$ below the water surface.

\section{DISCUSSION}

Because of limitations in the number of samplers that could be deployed within the permit granted by the Florida DEP, the results reported for both chemistry and groundwater discharge represent only a single sample from each sampling location. Thus, statistical evaluation of the data is not possible. The data are entirely consistent with those reported for conduit waters taken at several depths in Wekiwa and DeLeon Spring and from nearby wells by Franklin et al. (2005a; 2005b).

The samplers described here enabled acquisition of water samples from the bedrock limestone formation prior to its passing through the microbial mat that covers large expanses of the cave walls in the two freshwater submerged caves in which they were deployed. Additionally, the samplers proved useful in obtaining estimates of discharge into the cave from the surrounding porous bedrock. Lower concentrations of $\mathrm{SO}_{4}^{2-}$ within the host limestone compared to higher concentrations in the cave conduit suggested that $\mathrm{SO}_{4}^{2-}$ was being formed between the formation and the conduit, presumably in the microbial mat where sulfur-oxidizing bacteria are known to occur. That interpretation is also consistent with the presence of dissolved sulfide in the water from the formation and its absence in the conduit. The mass of sulfide oxidized did not balance the amount of $\mathrm{SO}_{4}^{2-}$ formed, although when expressed as $\mathrm{S}$, the differences are not as great as the numbers in Tab. 2 suggest. The water lost approximately $0.08 \mathrm{mg}$ sulfide-S $\mathrm{L}^{-1}$ and gained around $3.2 \mathrm{mg} \mathrm{SO}_{4}^{2-}-\mathrm{S} \mathrm{L}^{-1}$ (based on averaging all samples). The failure to close the mass balance cannot be explained at this point, but loss of sulfide from the samples prior to analysis, even though preserved with $\mathrm{Zn}^{2+}$, is a possibility, even though the results for the conduit for both sulfide and $\mathrm{SO}_{4}^{2-}$ agree favorably with those obtained by $\mathrm{R}$. B. Franklin (Herman et al. 2013). Nevertheless, trends in losses of sulfide and gains in $\mathrm{SO}_{4}^{2-}$ are in agreement and suggest the microbial mat is, indeed, generating $\mathrm{SO}_{4}^{2-}$ and associated protons from the reduced $\mathrm{S}$ emanating from the cave wall. Further use of the deployed samplers, and installation of some additional samplers in other positions, may help decipher the current imbalance in sulfur. Geochemical modeling of the system supports the idea that sulfide oxidation in this system can, indeed, account for substantial calcite dissolution (Herman et al. 2013). Thus, we have demonstrated that use of the device to recover samples for chemical analysis provided results that were consistent with the expectations of similar concentrations of some anions $\left(\mathrm{Cl}^{-}, \mathrm{NO}_{3}^{-}\right.$, and $\left.\mathrm{PO}_{4}^{3-}\right)$ in the wall and conduit, and substantial changes in concentration for others of interest ( $\mathrm{SO}_{4}^{2-}$, and dissolved sulfide).

Use of the samplers to measure seepage was an afterthought, and use of condoms to collect the water from the walls of the caves to quantify discharge into the conduit was based largely on our previous experience measuring inseepage in lakes and sandy-bottomed streams (Bruckner et al. 1984; Bruckner et al. 1989; Flewelling et al. 2012; Lehman \& Mills 1994; McIntire et al. 1987; McIntire et al. 1988). The use of condoms in measurement of discharge of water from porous media into open waters such as stream channels has been debated over the years, and there is not a clear consensus of opinion as to the suitability for seepage measurements. Many of the issues with condoms revolve around use for low-volumes and long time periods (e.g., Fellows \& Brezonik, 1980; Schincariol \& McNeil 2002). Problems such as deterioration of the condom with time or relaxation over long times as suggested by Schincariol \& McNeil (2002) are not issues with short deployment times. In a study comparing several types of bags with a dye-displacement meter that has no bag and therefore none of the problems associated with bags, Koopmans and Berg (2011) found that larger more rigid bags $(3.8 \mathrm{~L}$ zipper bags or 3.8-L twist-tie bags) similar to those used by other investigators exerted a positive pressure (expressed as a head differential, $\Delta \mathrm{h}$ ) that increased with increasing collection volume. The range of $\Delta \mathrm{h}$ was from around 0.1 to $70 \mathrm{~mm}$ as the bags filled. Thus, the bags exerted a strong resistance to flow. When condoms were used as collection bags, the head gradient was very slightly negative at around $-0.1 \mathrm{~mm}$, but the differential stayed constant until the condom reached its non-elastic limit at about $120 \mathrm{~mL}$. After that, the head gradient became strongly positive, as would be expected as the latex was forced to stretch. Koopmans and Berg (2011) concluded that seep- 
age meters that employ bags of any type are less sensitive than their dye-displacement meter, but that condoms represented a small source of error in measurement of smaller volumes $(<100 \mathrm{~mL})$ that compared favorably with the bagless version over short time periods (a few hours). In addition to the dye-displacement meters of Koopmans and Berg (2011), other types of meters have been developed that also use open flow paths (e.g., Paulsen et al. 2001; Rosenberry \& Morin 2004; Sholkovitz et al. 2003), but the expense and complexity of their operation make them impractical for deployment in numbers in submerged cave situations.

An obvious improvement in the device design for use as a discharge meter would be to employ a larger diameter in order to integrate a greater wall area. Drilling larger holes into the rock in these caves would be difficult at best, might destabilize materials of low cohesiveness, and would likely not be permitted by landowners or stewards in many diveable caves of interest.

Although we computed the specific discharge using the inner diameter of the sampler, the lower resistance to flow likely causes some greater volume of water to flow through the hollow chamber than would flow across an equivalent cross section of the porous limestone. Thus, the effective diameter of the sampler is probably slightly larger than the actual diameter. Because of the high permeability of the porous rock and the relatively low surface area of the drilled chamber, we believe that difference to be small and the true specific discharge to be only very slightly less than that computed with the diameter of the sampler chamber.

A question that arose during the initial installation was how long to wait before returning to collect sample.
Based on the observed discharge rates at Wekiwa and DeLeon Springs, and an assumed chamber volume of $125 \mathrm{~mL}$, the sample chambers would require between $6 \mathrm{hr}$ (Wekiwa deep sampler) and $96 \mathrm{hr}$ (Wekiwa shallow sampler) to replace the volume of the sampler with groundwater from the formation ( $\mathrm{T}=$ Volume / seepage rate), In Wekiwa and DeLeon Springs, the separation of installation and first sampling by a few days to a week should have resulted in complete turnover of all water inside the sample chamber and, therefore, collected samples are representative of the groundwater proximal to the cave wall surface. Because distilled or deionized water is injected into the sampler chamber to displace the native water, a similar amount of time should be allowed for purging of the diluted water in the chamber and complete replacement by groundwater prior to subsequent sample collection. While we did not do so, use of a solution containing a tracer not found in the native water, for example, $\mathrm{Br}$, could help determine if any dilution by the displacement water had occurred and, if it had, to determine the extent of dilution, allowing for correction of the results.

Use of the sample chambers installed in the cave walls of submerged caves can provide information to determine chemical changes in the water as it enters the conduit through the microbial mat. An added advantage of the design is that seepage rates can also be established for purposes of, for example, mixing calculations. Sampling frequency and the density of the installations are limited only by diver skill and availability, aside from any restrictions imposed by land owners or stewards on studies similar to the ones we are conducting with these devices.

\section{ACKNOWLEDGEMENTS}

The authors thank their project partners, the Cambrian Foundation for local coordination and intellectual and logistical support, and Florida DEP for permitted access to the springs which are located in State Parks. A number of individuals from the Cambrian Foundation played major roles in the conduct of this work, and the authors thank Renee Power and Kris Shannon for diving into the springs along with Tysall. We thank Amy Giannotti for overall coordination of the project in Florida, and for act- ing as the intermediary with Florida DEP. Special thanks go to Marissa Williams for campaign management; better organization and support cannot be imagined. The project was motivated by a cooperative effort with Rima Franklin at Virginia Commonwealth University who provided initial contact with the Cambrian Foundation and also provided initial logistical support through a grant (DEB 0920398) from the National Science Foundation. 


\section{REFERENCES}

Barton, H.A. \& F. Luiszer, 2005: Microbial metabolic structure in a sulfidic cave hot spring: potential mechanisms of biospeleogenesis.- Journal of Cave and Karst Studies, 67, 1, 28-38.

Brigmon, R.L., Martin, H.W., Morris, T.L., Bitton, G. \& S.G. Zam, 1994: Biogeochemical Ecology of Thiothrix Spp in Underwater Limestone Caves.- Geomicrobiology Journal, 12, 3, 141-159.

Bruckner, A.E., Hornberger, G.M. \& A.L. Mills, 1984: Groundwater seepage in a piedmont impoundment. Practical applications of groundwater models, Proceedings of the National Meeting on Groundwater Modeling. National Water Well Association, 570583.

Bruckner, A.E., Hornberger, G.M. \& A.L. Mills, 1989: Field measurement and associated controlling factors for groundwater seepage in a piedmont impoundment.- Hydrological Processes, 2, 223-235.

Chen, Y., Wu, L.Q., Boden, R., Hillebrand, A., Kumaresan, D., Moussard, H., Baciu, M., Lu, Y.H. \& J.C. Murrell, 2009: Life without light: microbial diversity and evidence of sulfur- and ammonium-based chemolithotrophy in Movile Cave.- ISME Journal, 3, 9, 1093-1104. 10.1038/ismej.2009.57.

Cline, J.D., 1969: Spectrophotometric determination of hydrogen sulfide in natural waters.- Limnology and Oceanography, 14, 454-458.

Engel, A.S., Lee, N., Porter, M.L., Stern, L.A., Bennett, P.C. \& M. Wagner, 2003: Filamentous "Epsilonproteobacteria" dominate microbial mats from sulfidic cave springs.- Applied and Environmental Microbiology, 69, 9, 5503-5511.

Engel, A.S. \& K.W. Randall, 2011: Experimental Evidence for Microbially Mediated Carbonate Dissolution from the Saline Water Zone of the Edwards Aquifer, Central Texas.- Geomicrobiology Journal, 28, 4, 313-327. 10.1080/01490451.2010.500197.

Engel, A.S., Stern, L.A. \& P.C. Bennett, 2004: Microbial contributions to cave formation: New insights into sulfuric acid speleogenesis.- Geology, 32, 5, 369372. 10.1130/g20288.1.

Erlich, H.L., 1996: Geomicrobiology. Marcel Dekker, Inc., New York, NY.

Fellows, C.R. \& P.L. Brezonik, 1980: Seepage Flow into Florida Lakes.- Water Resources Bulletin, 16, 4, 635-641. 10.1111/j.1752-1688.1980.tb02442.x.
Flewelling, S.A., Hornberger, G.M., Herman, J.S. \& A.L. Mills, 2012: Travel time controls the magnitude of nitrate discharge in groundwater bypassing the riparian zone to a stream on Virginia's coastal plain.Hydrological Processes, 26, 1242-1253. DOI: 10.1002/hyp.8219.

Franklin, R.B., Giannotti, A.L., Tysall, T.N. \& A.L. Mills, 2005a: Geomicrobiology of phreatic caves associated with central Florida springs, 30th Anniversary National Cave and Karst Management Symposium, Albany, New York.

Franklin, R.B., Tysall, T.N., Gianotti, A. \& A.L. Mills, 2005b: Geomicrobiology of phreatic caves associated with central Florida springs, Spring Meeting, American Geophysical Union, New Orleans, LA.

Herman, J.S., Hounshell, A.G., Franklin, R.B. \& A.L. Mills, 2013: Biological control on acid generation at the conduit-bedrock boundary in submerged caves: Quantification through geochemical modeling.Acta Carsologica, 42, 2, 45-57.

Holly, M.A., Lubetsky, J.S. \& C.F. Harvey, 2003: Characterizing submarine groundwater discharge: A seepage meter study in Waquoit Bay, Massachusetts.Geophysical Research Letters, 30, 6, 1297-1300. 10.1029/2002GL016000.

Koopmans, D.J. \& P. Berg, 2011: An alternative to traditional seepage meters: Dye displacement.Water Resources Research, 47, 1, W01506. 10.1029/2010WR009113.

Lee, D.H., 1977: A device for measuring seepage flux in lakes and estuaries.- Limnology and Oceanography, 22, 1, 140-147.

Lehman, R.M. \& A.L. Mills, 1994: Field evidence for copper mobilization by dissolved organic matter.Water Research, 28, 2487-2497.

Lock, M.A. \& P.H. John, 1978: Measurement of Groundwater Discharge into a Lake by a Direct method.Internationale revue der gesamten hydrobiologie, 63, 2, 271-275. 10.1002/iroh.19780630212.

McIntire, P.E., Mills, A.L. \& G.M. Hornberger, 1987: A groundwater seepage meter for use in lakes with low groundwater flow and high biogenic gas production, Annual Meeting of the American Geophysical Union, San Francisco, CA.

McIntire, P.E., Mills, A.L. \& G.M. Hornberger, 1988: Groundwater lake interactions and the occurrence of high sulfate concentrations at depth in the sediment of Lake Anna, Virginia.- Hydrologic Processes, 2, 207-217. 
Otte, M.L. \& J.T. Morris, 1994: Dimethylsulphoniopropionate (DMSP) in Spartina Alterniflora Loisel.Aquatic Botany, 48, 3-4, 239-259.

Paulsen, R.J., Smith, C.F., O'Rourke, D. \& T.F. Wong, 2001: Development and evaluation of an ultrasonic ground water seepage meter.- Ground Water, 39, 6. doi:10.1111/j.1745-6584.2001.tb02478.x.

Rosenberry, D.O. \& R.H. Morin, 2004: Use of an electromagnetic seepage meter to investigate temporal variability in lake seepage.- Ground Water, 42, 1, 68-77. 10.1111/j.1745-6584.2004.tb02451.x.

Sacks, L.A. 1996: Geochemical and isotopic composition of ground water with emphasis on sources of sulfate in the Upper Floridan aquifer in parts of Marion Sumter, and Citrus Counties, Florida, U.S. Geological Survey Water-Resources Investigations Report: 95-4251.

Sarbu, S.M., Kane, T.C. \& B.K. Kinkle, 1996: A chemoautotrophically based cave ecosystem.- Science, 272, 5270, 1953-1955.
Schincariol, R.A. \& J.D. McNeil, 2002: Errors with small volume elastic seepage meter bags.- Ground Water, 40, 6, 649-651. 10.1111/j.1745-6584.2002. tb02551.x.

Sholkovitz, E., Herbold, C. \& M. Charette, 2003: An automated dye-dilution based seepage meter for the time-series measurement of submarine groundwater discharge.- Limnology \& Oceanography Methods, 1, 16-28.

Stumm, W. \& J.J. Morgan, 1996: Aquatic Chemistry: Chemical Equilibria and Rates in Natural Waters. John Wiley \& Sons, Inc., New York, NY, 1022.

Vlasceanu, L., Sarbu, S.M., Engel, A.S. \& B.K. Kinkle, 2000: Acidic cave-wall biofilms located in the Frasassi Gorge, Italy.- Geomicrobiology Journal, 17, 2, 125-139. 